\title{
KITAB KUNING DAN MADRASAH: STUDI PADA PONDOK PESANTREN HIKMATUSYSYARIEF NW SALUT SELAT LOMBOK BARAT
}

\author{
Abd. Muin M \\ Puslitbang Pendidikan Agama dan Keagamaan | Balitbang dan Diklat Kemenag RI \\ Jl. MH Thamrin No.6 Jakarta Pusat | Email: fikri_iqbale@yahoo.com
}

\begin{abstract}
This study attempts to uncover the education background of Islamic boarding school's educator, the students' motivation levels in studying yellow book and education system of Islamic boarding school. Through the qualitative method, the researcher conducted interviews with key informants, observed the education facilities and activities of the students, as well as studied the Islamic boarding school documents, which then lead to the collection of the data and information related to this research issues. The research result shows: (1) With "very adequate" Islamic boarding school education background, the educators of Hikmatusy syarief Islamic boarding school have successfully maintained and preserved the Islamic boarding school system, especially in studying yellow book with madrasah education system. (2) Most of the students have a strong motivation to study yellow book. (3) Values and elements of the education system of this Islamic boarding school is a single unit that integrated, complete each other and strengthen the implementation of the yellow book learning and madrasah education.
\end{abstract}

Keywords: Yellow book, Madrasah, Continuity, Changes

\section{Abstrak}

Penelitian ini bertujuan untuk mengungkapkan latar belakang pendidikan pengasuh pesantren, tingkat motivasi santri mengaji kitab kuning dan sistem pendidikan pesantren. Melalui metode kualitatif peneliti melakukan wawancara dengan informan kunci, mengobservasi sarana pendidikan dan aktivitas santri, serta mempelajari dokumen-dokumen pesantren, akhirny a dikumpulkan data dan informasi yang berkaitan masalah penelitian ini. Hasil penelitian menunjukkan: (1) Dengan berlatar belakang pendidikan pesantren yang "sangat memadai", Pengasuh Pesantren Hikmatusysyarief sukses mempertahankan dan melesatarikan sistem pesantren, khususnya pengajian kitab kuning dengan sistem pendidikan madrasah. (2) Sebagian besar santri memiliki motivasi yang kuat mengaji kitab kuning. (3 Nilai-nilai dan unsur-unsur sistem pendidikan pesantren ini merupakan satu kesatuan yang terpadu, saling melengkapi dan memperkuat pelaksanaan pengajian kitab kuning dan pendidikan madrasah.

Kata Kunci: Kitab Kuning, Madrasah, Kelangsungan, Perubahan

\section{PENDAHULUAN}

Pesantren di Provinsi Nusa Tenggara Barat tahun 2012 berjumlah 588, di antaranya 577 (98,13\%) pesantren menyelenggarakan pendidikan formal (madrasah/sekolah) dan 11 $(1,87 \%)$ tidak menyelenggarakan pendidikan formal. ${ }^{1}$ Ini berarti, sebagian besar pesantren meyelenggarakan pendidikan formal. Menurut Steenbrinkpesantren yang diaturlebihmodern,

${ }^{1}$ Sumber: Data Pondok Pesantren Kanwil Kementerian Agama Provinsi NTB, tahun 2012.

Naskah diterima 30 Februari 2014. Revisi pertama, 10 Maret 2014. Revisi kedua, 20 Maret 2014 dan revisi terahir 5 April 2014. 
di samping ada sistem pendidikan tradisional, juga terdapat madrasah dalam pesantren yang dipungut iuran. ${ }^{2}$ Selain itu, menurut Saridjo setelah kemerdekaan banyak pesantren yang menyesuaikan diri dengan tuntutan keadaan antara lain menyelenggarakan pendidikan formal terutama madrasah, di samping tetap meneruskan sistem wetonan dan sorogan. ${ }^{3}$

Kepala Kanwil Kementerian Agama Provinsi Nusa Tenggara Barat mengemukakan, bahwa pesantren yang menyelenggarakan pendidikan formal (madrasah atau sekolah) tetap melaksanakan pengajian kitabkitab kuning untuk mempartahankan dan memperkuat tradisi dan karakter pesantren sebagai lembaga pendidikan tafaqquh fi al-din. Namun, pengajian kitab-kitab kuning antara satu pesantren dengan pesantren lainnya cukup bervariasi. Hal ini sangat ditentukan oleh latar belakang pendidikan pendiri dan pengasuh pesantren tersebut. ${ }^{4}$

Pesantren Hikmatusysyarief, selain aktif menyelenggarakan pengajian kitab kuning sebagai pengajaran utama yang wajib diikuti seluruh santri. Juga menyelenggarakan madrasah (pendidikan formal) yang mengajarkan mata pelajaran umum. Kehadiran madrasah di pesantren ini tidak dimaksudkan menggusur pengajian kitab kuning. Sebaliknya, pengajian kitab kuning tidak menganaktirikan pelajaran umum pada madrasah. Tapi baik pengajian kitab kuning maupun pelajaran umum diharapkan saling mendukung, melengkapi dan memperkuat, sehingga kehadiran madrasah di pesantren semakin mempertegas langkah pengasuh pesantren dalam memenuhI kebutuhan masyarakat. Namun, bagaimana Pesantren Hikmatusysyarief, apakah sistem pendidikan pesantren dapat berjalan seirama dengan

${ }^{2}$ Karel A. Steenbrink. 1994. Pesantren Madrasah Sekolah Pendidik an Islam Dalam Kurun Waktu Modern. Jakarta: LP3ES, h. 127.

${ }^{3}$ Marwan Saridjo et. el. 1982. Sejarah Pondok Pesantren di Indonesia. Jakarta: Dharma Bhakti. h. 59. 2012.

${ }^{4}$ Wawancara dilakukan pada tanggal 31 Oktober madrasah (pendidikan formal), di sinilah letak urgensi dan siginifikansi penelitian ini.

Survei Pengajaran Kitab Kuning oleh Puslitbang Pendidikan Agama dan Keagamaan tahun 2011, diketahui dari289 kitab kuningyang disurvei, frekuensi pengajaran kitab kuning dalam beragam bidang keilmuan tergolong "rendah" (12,3\%) dilihat dari frekuensi pengajaran kitab-kitab pilihan kyai dan 10,3\% pilihan santri. ${ }^{5}$ Diduga faktor penyebabnya, antara lain: pengasuh (pimpinan) pesantren tidak berlatar belakang pendidikan pesantren; siswa madrasah sebagai santri pesantren tidak memiliki motivasi kuat belajar (mengaji) kitab kuning, dan sistem pendidikan pesantren tidak mendukung pelaksanaan pengajian kitab kuning. Untuk itu, posisi penelitian ini merupakan lanjutan survei tahun 2011 untuk memperjelas secara emperis berbagai dugaan tersebut.

Dengan demikian, fokus masalah dalam tulisan ini, adalah bagaimana: (1) latar belakang pendidikan pengasuh pesantren, (2) tingkat motivasi santri terhadap pengajian kitab kuning dan (3) sistem pendidikan pesantren. Untuk itu, penelitian ini bertujuan untuk mengungkapkan: (1) latar belakang pendidikan pengasuh pesantren, (2) tingkat motivasi santri mengaji kitab kuning dan (3) sistem pendidikan pesantren.

Hasil penelitian ini diharapkan bermanfaat bagi Direktorat Jenderal Pendidikan Islam Kementerian Agama sebagai masukan dalm menyusun dan menetapkan kebijakan pembinaan pesantren, khususnya pesantren yang aktif menyelenggarakan pengajian kitab kuning dan pendidikan formal.

${ }^{5}$ Husen Hasan Basri, dkk. 2011. Survei Pengajaran Kitab Kuning di Pondok Pesantren. Jakarta: Puslitbang Pendidikan Agama dan Keagamaan Badan Litbang dan Diklat Kemenag, h. 112. 


\section{Kerangka Konseptual}

\section{Kitab Kuning}

Pengertian kitab kuning cukup beragam, di antaranya menurut Pengasuh Pesantren Hikmatusysyarief TGH. Zahid Syarief, kitab kuning merupakan kitab-kitab keagamaan berbahasaArabyangtidakberbaris (gundul) dan ditulis oleh ulama/ kyai besar yang menguasai secara mendalam ilmu-ilmu agama Islam dan menjadi panutan (tauladan) masyarakat dalam berbagai aspek kehidupannya. ${ }^{6}$ Menurut Azra, kitab kuning pada umumnya dipahami sebagai kitab-kitab keagamaan berbahasa Arab, menggunakan aksara Arab, yang dihasilkan oleh para 'ulama dan pemikir Muslim lainnya di masa lampau-khususnya yang berasal dari Timur Tengah. Dalam pengertian yang luas, kitab kuning sebagai kitab-kitab keagamaan berbahasa Arab, Melayu atau Jawa atau bahasa-bahasa lokal lain di Indonesia dengan menggunakan aksara Arab, yang selain ditulis oleh 'ulama di Timur Tengah, juga ditulis oleh'ulama Indonesia sendiri. ${ }^{7}$

Kitab-kitab klasik (kitab kuning) yang diajarkan di pesantren, Dhofier menggolongkan ke dalam 8 kelompok jenis pengetahuan: 1. nahwu dan shorof; 2. fiqh; 3. usul figh; 4. hadits; 5. tafsir; 6. tauhid; 7. tasawuf dan etika, dan 8. cabang-cabang lain seperti tarikh dan balaghah. Kitab-kitab ini digolongkan tiga tingkatan: 1. Kitab dasar; 2. Kitab menengah dan 3. kitab tingkat tinggi. ${ }^{8}$

Berdasarkan uraian di atas, disimpulkan bahwa yang dimaksud kitab kuning dalam penelitian ini adalah kitab-kitab keagamaan berbahasa Arab yang tidak berbaris dan ditulis baik oleh ulama besar Timur Tengah maupun ulama Indonesia yang menguasai secara

${ }^{6}$ Wawancara pada tanggal 2 November 2012

${ }^{7}$ Azyumardi Azra. 2002. Pendidikan Islam: Tradisi dan Modernisasi Menuju Milenium Baru. Jakarta: Logos Wacana Ilmu dan Pemikiran, h. 111.

${ }^{8}$ Zamakhsyari Dhofier. 2011. Tradisi Pesantren: Studi Pandangan Hidup Kyai dan Visinya Mengenai Masa Depan Indonesia. Jakarta: LP3ES, h. 87. mendalam ilmu-ilmu agama Islam dengan menggunakan bahasa Arab, Melayu atau Jawa atau bahasa-bahasa lokal lainnya di wilayah Indonesia. Sedangkan kitab-kitab kuning yang diajarkan di pesantren ini, meliputi: nahwushorf, fiqh, usul fiqh, hadits, tafsir, tauhid dan faraid.

\section{Sistem Pendidikan Madrasah}

Peraturan Menteri Agama Nomor 90 Tahun 2013 tentang Penyelenggaraan Pendidikan Madrasah, Pasal 1 ayat (2) menyebutkan madrasah adalah satuan pendidikan formal dalam binaan Menteri Agama yang menyelenggarakan pendidikan umum dan kejuruan dengan kekhasan agama Islam yang mencakup Raudhatul Atfal, Madrasah Ibtidaiyah, Madrasah Tsanawiyah, Madrasah Aliyah dan Madrasah Aliyah Kejuruan.

Madrasah sebagai satuan pendidikan formal, penyelenggaraannya harus berdasarkan kebijakan pemerintah. Menurut Rahim guru di madrasah wajib memenuhi kualifikasi akademik, kompetensi, sertifikat pendidik dan memiliki kemampuan untuk mewujudkan tujuan pendidikan nasional. Juga, kurikulum madrasah harus terstandarkan. Karena itu, madrasah dituntut melakukan berbagai perubahan penting dan strategis dalam bidang manajemen. ${ }^{9}$

Dengan demikian, pendidikan madrasah dalam penelitian ini adalah MTs dan MA di lingkungan pesantren. Selain itu, MTs dan MA ini dalam binaan Menteri Agama yang mengajarkan mata pelajaran umum dan gurugurunya memenuhi kualifikasi akademik, kompetensi dan standirisasi pendidikan lainnya.

\section{Metodologi Penelitian}

Sesungguhnya sejak dulu pesantren telah menyelenggarakan pendidikan formal

${ }^{9}$ Husni Rahim. 2001. Arah Baru Pendidikan Islam di Indonesia. Jakarta: Logos. h. 21 
(madrasah/sekolah) yang mengajarkan mata pelajaran umum di lingkungan pesantren. Menurut Azra, Pesantren Mambaul Ulum Surakarta 1906 merupakan perintis dari penerimaan mata pelajaran umum dalam pendidikan pesantren. Kemudian 1916 Pesantren Tebuireng mendirikan "Madrasah Salafiyah" yang tidak hanya mengadopsi sistem pendidikan modern, tapi juga memasukkan pelajaran umum. Selanjutnya 1927 Pesantren Rejoso mendirikan madrasah, juga memperkenalkan mata pelajaran nonkeagamaan dalam kurikulumnya. ${ }^{10}$

Begitupun pesantren di Provinsi Nusa Tenggara Barat sejak dulu telah menyelenggarakan pendidikan formal (madrasah/ sekolah). Namun, umumnya pesantren tersebut tidak seluruh santrinya mukim di pesantren, misalnya; Pesantren Nurul Hakim Lombok Barat, Pesantren Darul Muhajirin Lombok Tengah, Pesantren Al Majidiyah NW Kesik Lombok Timur. Sedangkan Pesantren Hikmatusysyarief NW Salut seluruh santrinya mukim di pesantren.

Oleh karena itu, penelitian ini dilaksanakan di Pesantren Hikmatusysyarief NW Salut Selat Lombok Barat dengan alasan, antara lain: (1) seluruh santrinya wajib mukim, (2) tetap mempertahankan dan memelihara berbagai tradisi kepesantrenan, khususnya tradisi pengajian kitab kuning dengan metode bandongan atau wetonan dan halaqah yang wajib diikuti seluruh santri, (3) menyelenggarakan pendidikan formal (madrasah) di lingkungan pesantren. (4) diduga telah berhasil memadukan penyelenggaraan sistem pendidikan pesantren (pengajian kitab kuning) dengan pendidikan formal (madrasah).

Penelitian ini menggunakan metode kualitatif dengan alasan, antara lain: (1) memungkinkan peneliti untuk melihat perilaku dalam situasi yang sebenarnya tanpa adanya rekayasa; (2) dapat meningkatkan kedalaman pemahaman peneliti terhadap fenomena

\footnotetext{
${ }^{10}$ Azyumardi Azra. Op. Cit., h. 100.
}

yang diteliti; (3) bersifat fleksibel sehingga memungkinkan peneliti untuk mempelajari berbagai bidang baru yang menarik. ${ }^{11}$

Sementara itu sumber dan teknik pengumpulan data sebagaimana menurut Lofland dan Lofland sumber data primer dalam penelitian kualitatif adalah kata-kata dan tindakan, lainnya adalah data sekunder, seperti dokumen dan lainnya. ${ }^{12}$ Data primer diperoleh dari informan kunci yang ditetapkan melalui metode snowball. Untuk itu, peneliti secara acak menghubungi sejumlah informan yang dipandang mampu memberi informasi atau data yang akurat tentang masalah penelitian ini. Selanjutnya dari informan tersebut, peneliti meminta merekomendasikan kepada informan lainnya, begitulah seterusnya sampai peneliti tidak menemukan informasi atau data yang baru lagi. Kata-kata dan tindakan dari sumber data primer, peneliti memperolehnya melalui berbagai teknik pengumpulan data: (a) Wawancara mendalam, dilakukan dengan informan kunci, yaitu para pelaku yang memiliki peran penting dan strategi di pesantren ini. (b) Observasi partisipan, dilakukan terhadap berbagai kegiatan santri, seperti; pengajian kitab kuning di pemondokan, di masjid dan di ruang kelas madrasah yang dilaksanakan pada pagi hari, sore hari dan malam hari. Juga observasi dilakukan dalam proses pembelajaran di madrasah, kehidupan santri di pemondokan, shalat berjama'ah dan aktivitas lainnya. Observasi ini dilakukan dengan tujuan untuk mengetahui secara langsung, utuh dan obyektif fenomena yang diteliti dengan menggunakan pendekatan emik, sehingga peneliti dapat memahami dan memaknai simbol-simbol tersebut. (c) Kuesioner, untuk mengetahui tingkat motivasi santri terhadap pengajian kitab kuning, maka peneliti menyusun 5 item kuesioner yang terkait dengan indikator motivasi dan

${ }^{11}$ Morissan. 2012. Metode Penelitian Survei. Jakarta: Kencana Prenada Media Group, h. 22.

${ }^{12}$ John Lofland \& Lyn H Lofland. 1984. Analyzing Social Settings: A. Guide to Qualitative Observation and Analysis. Belmont, Cal.: Wads worth Publishing Company, h. 47. 
membagikannya secara random kepada 45 santri kelas $12 \mathrm{MA}$, dengan alasan santri ini sudah 6 tahun belajar di pesantren/madrasah ini. (d) Dokumen, sumber data sekunder peneliti memperolehnya melalui dokumen yang berkaitan masalah penelitian, antara lain; laporan perkembangan pesantren ini.

Analisis data dilakukan dengan "analisis deskriptif kualitatif dan verifikatif kualitatif". Untuk itu, peneliti melakukan kategorisasi dan klasifikasi data yang telah diperoleh dari lapangan. Sedangkan untuk menguji validitas data, peneliti memverifikasi dan membandingkan data dari berbagai sumber, baik sumber lisan dan tindakan melalui wawancara, tulisan (dokumen) maupun data yang diperoleh melalui obersevasi. Informasi atau data tentang masalah penelitian yang telah diperoleh, kemudian diperlajari secara cermat, dianalisis, dibahas dan ditelaah dengan mendalam, setelah itu dilakukan editing, deskripsi dan verifikasi.

\section{HASIL DAN PEMBAHASAN}

\section{Latar Belakang Pendidikan Pengasuh Pesantren}

TGH. Muhammad Zahid Syarief sebagai perintis, pendiri dan pengasuh Pesantren Hikmatusysyarief NW Salut, merupakan salah satu komponen penting dan strategi dalam sistem pendidikan pesantren ini, terutama berkaitan dengan lembaga pendidikan tempat belajar, berapa lama dan kepada kyai siapa belajar serta bidang keahliannya, khususnya terkait dengan kitab kuning.

Syarief mengawali pendidikannya di sekolah agama di Pancor Lombok Timur di bawah pengasuhan Maulana Syekh TGH. Muhammad Zainuddin Abd. Madjid selama 7 tahun. Kemudian Syarief melanjutkan pendidikannya ke Perguruan Hamzan Wadi (setingkat Ma'hadAli) selama 4 tahun. Meskipun sudah lulus, beliau tidak diperkenankan oleh TGH. Zainuddin meninggalkan perguruan ini. Akhirnya, Syarief diamanati mengasuh
Madrasah Mu'allimin 4 tahun. Keberhasilan beliau, 1973 TGH. Zainuddin memberangkatkan Syarief ke Mekkah untuk lebih memperdalam ilmu agama melalui berbagai kajian kitab-kitab Islam klasik.

Almamater yang dituju Syarief adalah perguruan tempat belajar TGH. Zainuddin, yaitu Madrasah Ash-Shaulatiyah, akhirnya 1977 (selama 4 tahun) secara formal Syarief menyelesaikan pendidikannya setelah diuji kemampuannya oleh beberapa Syekh melalui dialog dan mengaji dari syekh yang satu ke syekh lain selama 4,5 tahun, sehingga selama 8,5 tahun Syarief memperdalam ilmu-ilmu agama di Mekkah. Pertengahan 1981, Syarief kembali ke kampung halamannya dan sampai sekarang tidak pernah berhenti mengamalkan ilmunya.

Uraian di atas, menunjukkan bahwaTGH. M Zahid Syarief memiliki latar belakang pendidikan pesantren yang "sangat memadai" dengan keahlian "nahwu-sharf", sehingga dalam kapasitasnya sebagai pengasuh dan pucuk pimpinan pesantren ini mampu merespon secara cepat dan tepat setiap gagasan, terutama jika gagasan tersebut relevan dengan kebutuhan masyarakat. Karena itu, pengasuh pesantren ini menyikapi berbagai inovasi yang dianggap tidak hanya mendukung kelangsungan dan perubahan (continuity and change) sistem pendidikan pesantren, tapi juga bermanfaat bagi santri dengan tetap berpegang teguh kepada prinsip kaidah fiqh "al muhafadzatu 'ala al qadimi al shalih wa al ahdu bi al jadid al aslah". Untuk itu, dalam melakukan adaptasi dan inovasi, pengasuh pesantren tetap memelihara dan mempertahankan tradisi pesantren sebagai lembaga pendidikan keagamaan yang lebih mengutamakan tafaqquh fi al-din melalui pengajian kitab kuning. Ini berarti, bahwa sesungguhnya tuan guru telah berperan aktif dalam mengantisipasi dan mengadaptasi agenda perubahan sosial yang relevan dengan kebutuhan nyata masyarakat. 


\section{Santri}

\section{Motivasi Santri}

Menurut Morgan motivasi merupakan tenaga pendorong atau penarik yang dapat melahirkan tingkah laku untuk mencapai suatu tujuan. ${ }^{13}$ Dalam hal ini, motivasi diartikan sebagai tenaga pembangkit untuk mendorong, menyemangati dan menarik santri agar lebih bersungguh-sungguh menghadiri, memperhatikan, meluangkan waktu dan menyelesaikan tugas-tugas dalam mengikuti pengajian kitab kuning di pesantren ini, baik pengajian kitab kuning yang dilaksanakan ba'da shubuh di masjid, sore hari di ruang belajar madrasah maupun malam hari di pemondokan.

Berkaitan dengan itu, menurut Worrel dan Stilwill dalam Muhaimin, indikator motivasi: (1) bersungguh-sungguh, menunjukkan minat, mempunyai perhatian dan rasa ingin tahu yang kuat untuk ikut serta dalam kegiatan belajar; (2) berusaha keras dan memberikan waktu yang cukup untuk melakukan kegiatan tersebut; (3) terus bekerja sampai tugas-tugas tersebut terselesaikan. ${ }^{14}$

a. Tingkat kehadiran santri dalam pengajian kitab kuning

Kesungguhan santridalam menghadiri pengajian kitab kuning dapat diketahui dari tingkat kehadiran santri. Ternyata sebagian besar santri menyatakan selalu hadir pada setiap pelaksanaan pengajian kitab kuning. Ini menunjukkan, sebagian besar santri memiliki motivasi yang kuat untuk belajar kitab kuning.

${ }^{13}$ Morgan. et al. 1986. Instructional to Psychology. New York: McGraw-Hill Book Co., h. 73.

${ }^{14}$ Muhaimin. Op. Cit., h. 138.
Grafik: 01

Tingkat Kehadiran Santri dalam Pengajian Kitab Kuning

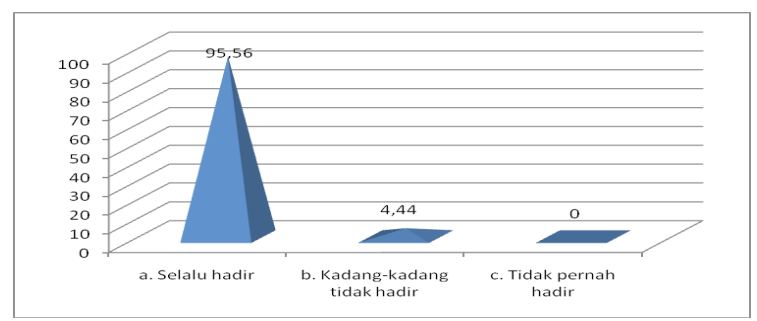

Meskipun demikian, berdasarkan observasi dapat diketahui bahwa tingkat kehadiran santri dalam menghadiri pembelajaran di madrasah lebih baik, yaitu seluruh santri hadir tepat waktunya. Jika dibanding dengan kehadiran santri dalam pengajian kitab kuning masih terdapat sebagian kecil santri yang kadang-kadang tidak hadir, juga masih ada beberapa santri yang kehadirannya terlambat. ${ }^{15}$

b. Perhatian santri pada waktu pengajian kitab kuning

Ketika santri sedang mengikuti pengajian kitab kuning, perhatian santri terhadap penjelasan tuan guru atau ustadz merupakan faktor yang penting dan strategi untuk dapat menyerap secara maksimal materi pengajian tersebut. Dalam hal ini, terdapat sebagian besar santri menyatakan mereka selalu memperhatikan penjelasan tuan guru atau ustadz, hanya sebagian kecil yang kadang-kadang memperhatikannya. Ini berarti, bahwa hampir dapat dipastikan sebagian besar santri dapat menyimak dan menyerap dengan baik materi pengajian.
15 Hasil observasi terhadap kehadiran santri mengikuti pengajian kitab kuning dan mengikuti pembelajaran di madrasah (pendidikan formal) yang dilakukan tanggal 1 - 5 November 2012. 
Grafik: 02

Perhatian Santri Pada Waktu Pengajian Kitab Kuning

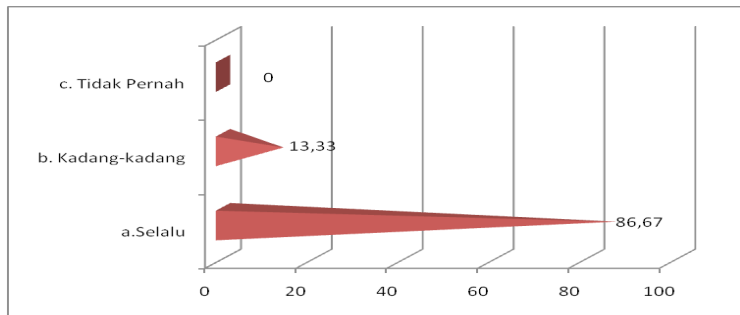

c. Meluangkan waktu untuk mengaji kitab kuning

Mengingat jadwal pembelajaran santri sangat padat, sebab selain belajar di madrasah, juga di pesantren. Karena itu, santri dituntut kemampuannya untuk mengatur waktunya sesuai jadwal yang telah ditetapkan. Sehingga santri dapat menghadiri setiap jadwal pembelajaran, khususnya mengaji kitab kuning, baik belajar secara mandiri, berkelompok (tutor sebaya) maupun mengaji dengan tuan guru atau ustadz. Hal ini merupakan hal yang sangat berharga untuk lebih memahami dan menguasai kitab kuning. Sebab, jika seorang santri sering tidak meluangkan waktunya untuk mengikuti pengajian kitab kuning, jelas merupakan hambatan bagi santri tersebut untuk lebih meningkatkan pehamaman dan penguasaannya terhadap kitab kuning tersebut.

Berkaitan dengan hal itu, ternyata sebagian besar santri selalu meluangkan waktunya untuk belajar kitab kuning. Ini menunjukkan, bahwa sebagian besar santri memiliki potensi dan peluang yang sangat besar untuk berhasil dalam pengajian kitab kuning.
Grafik: 03

Meluangkan Waktu Untuk Mengaji Kitab Kuning

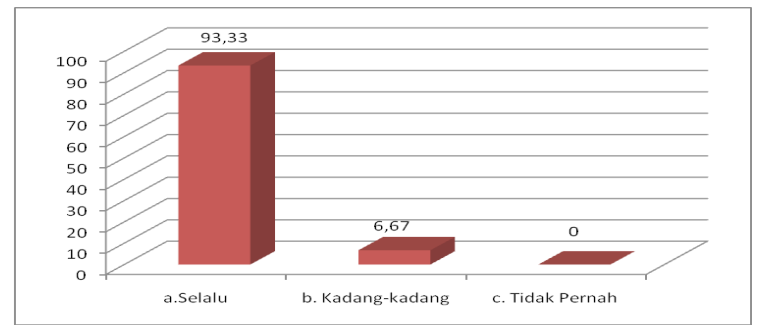

d. Menyelesaikan tugas yang berkaitan dengan pengajian kitab kuning

Santri di pesantren ini memiliki tugas yang relatif banyak, sehingga waktu selama dua puluh empat jam seakan-akan tidak cukup untuk menyelesaikan tugastugasnya, baik tugas-tugas yang berkaitan dengan pembelajaran di madrasah maupun pengajian kitab kuning. Namun, setiap santri dituntut harus menyelesaikan tugas-tugasnya. Jika tidak, santri tersebut dipastikan mendapat hukuman. Dalam hal ini, ketika ustadz Humaidy menjelaskan tentang "hukuman" beliau mengutip pendapat Athiyyah Al Abrasyi dalam Kitab At Tarbiyyah Al Islamiyyah, mengemukakan bahwa hukuman kepada santri di pesantren ini sebenarnya lebih bersifat mendidik. Artinya, hukuman dilakukan untuk mendidik santri dan sama sekali tidak ada rasa dendam atau sakit hati kepada santri yang dihukum. Tapi, sematamata bertujuan untuk membimbing, menasehati dan membina agar santri selalu berada pada jalan yang sesuai nilainilai ajaran Islam. Selain itu, hukuman tersebut sebagai upaya untuk memotivasi santri agar kelak menjadi orang yang percaya diri, dinamis, inovatif, kreatif dan produktif. Karena itu, hukuman tersebut bukan hukuman fisik dan psikis yang menyababkan santri ketakutan dan dapat mempengaruhi tingkat kecerdasan dan kreativitasnya. ${ }^{16}$

${ }^{16}$ Wawancara pada tanggal 2 November 2012. 
Meskipun demikian, ternyata sebagian besar santri menyatakan selalu menyelesaikan tugas-tugasnya, misalnya; menghafal Kitab Qawaidul Lughatul Arabiyyah, Kitab Ta'limul Muta'allim, Kitab Matnul Jurumiyyah dan kitab-kitab lainnya tepat pada waktunya. Ini berarti, sebagian besar santri di pesantren ini memiliki semangat untuk bekerja keras dalam menyelsaikan tugas-tugasnya. Indikasi ini menunjukkan bahwa sebagian besar santri di pesantren ini memiliki motivasi yang tinggi untuk mengaji kitab kuning.

Grafik: 04

Menyelesaikan Tugas dari Pengajian Kitab Kuning

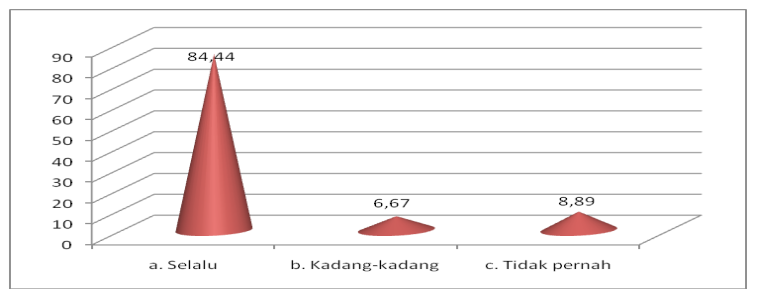

e. Alasan santri mengaji kitab kuning

Adanya sebagian besar santri memiliki motivasi untuk mengaji kitab kuning sebagaimana uraian di atas. Pada dasarnya didorong dan disemangati oleh keinginan yang kuat untuk mengatahui isi dan kandungan kitab kuning tersebut. Hal ini merupakan alasan yang dikemukakan sebagian besar santri sehingga mereka belajar kitab kuning.

Grafik: 05

Alasan Santri Mengaji Kitab Kuning

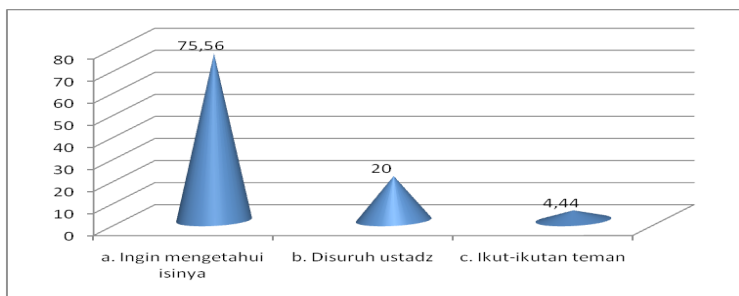

Dorongan keinginan ini merupakan motivasi yang lahir dari dalam diri sendiri santri (intrinsik). Hal ini merupakan kesadaran yang sangat positif, mengingat pada saat ini keinginan anak-anak muda cenderung kurang bermotivasi mempelajari (mengaji) kitab kuning. Selain itu, terdapat pula motivasi santri untuk mengaji kitab kuning yang lahir disebabkan oleh motivasi dari luar (ekstrinsik), misalnya; santri bersungguhsungguh mengaji kitab kuning karena disuruh oleh ustadz dan/atau ikuta-ikutan temannya. Namun, hal ini hanya sebagian kecil santri yang menyatakan demikian.

Uraian di atas, menggambarkan bahwa terdapat sebagian besar santri di pesantren ini memiliki motivasi yang besar untuk mempelajari (mengaji) kitab kuning. Hal ini merupakan hal yang sangat positif sebagai upaya untuk lebih menumbuh-kembangkan fungsi-fungsi tradisional pesantren, yaitu: pertama, transmisi dan transfer ilmu-ilmu Islam; kedua, pemeliharaan tradisi Islam, dan ketiga reproduksi ulama. ${ }^{17}$ Juga hal ini merupakan peluang besar bagi pengasuh (tuan guru) untuk lebih meningkatkan efektifitas pengajian.

Meskipun demikian, berdasarkan hasil observasi dapat diketahui bahwa motivasi santri untuk mempelajari mata pelajaran umum di madrasah masih lebih kuat, jika dibanding dengan motivasi santri untuk mengaji kitab kuning. ${ }^{18} \mathrm{Hal} \mathrm{ini}$ diketahui adanya semua siswa hadir tepat waktu di madrasah dan semua tugas-tugas diselesaikan. Sedangkan pada pengajian kitab masih terdapat beberapa santri yang terlambat dan juga tidak menyelesaikan tugas-tugasnya. Kondisi ini merupakan tantangan bagi pengasuh (tuan guru) untuk selalu berupaya secara maksimal, agar seluruh santri memiliki motivasi

\footnotetext{
${ }^{17}$ Azymardi Azra. Op. Cit., h. 104

${ }^{18}$ Hasil observasi yang dilakukan pada tanggal 1 - 5 November 2012.
} 
yang lebih besar untuk mengaji kitab kuning, sebagaimana halnya motivasi santri mempelajari mata pelajaran umum, sehingga pesantren sebagai lembaga pendidikan keagamaan Islam, selain dapat memperkuat tafaqquh fi al-din, juga memperkuat sains dan teknologi.

\section{Jumlah Santri}

Pesantren Hikmatusysyarief NW sejak beridiri tahun 1990 sampai sekarang jumlah santrinya stabil (konstan), yaitu sekitar 500an orang. Pada tahun 2012, jumlah santri 503 orang, terdiri dari laki-laki 225 (44,73\%) dan perempuan $278(55,27 \%)$ orang. Ini befarti, santri perempuan lebih banyak dari santri laki-laki. Santri-santri tersebut tidak hanya berasal dari provinsi ini, tapi juga berasal dari provinsi lainnya.

Kestabilan jumlah santri tersebut, menggambarkan bahwa pengasuh dan asatidz Pesantren Hikmatusysyarief telah berhasil memberikan pelayanan pendidikan sesuai kebutuhan masyarakat, baik pendidikan pesantren maupun pendidikan formal (madrasah), sehingga saling mendukung dan melengkapi. Karena itu, santri di pesantren ini, selain dapat menyerap ilmu umum, juga ilmu agama Islam melalui pengajian kitab kuning. Faktor ini dapat menumbuhkan kepercayaan masyarakat untuk menentukan pesantren ini sebagai pilihan utama tempat belajar anaknya.

Oleh karena itu, kepercayaan masyarakat terhadap pesantren ini memegang peranan sebagai magnit yang kuat untuk membangkitkan semangat dan minat masyarakat memasukkan anaknya belajar, sehingga jumlah santrinya setiap tahun stabil (konstan). Bahkan, jika seandainya ruang belajar di madrasah dan daya tampung pemondokan lebih besar, dapat dipastikan setiap tahun dapat mengalami perkembangan jumlah santri yang lebih besar lagi.

Uraian di atas, menunjukkan bahwa betapa besar harapan masyarakatterhadap pendidikan di pesantren. Ini dibuktikan dengan tingginya animo masyarakat memasukkan anaknya menuntut ilmu pengetahuan di pesantren. Hal ini didukung oleh motivasi santri yang tinggi untuk belajar (mengaji) kitab kuning. Ini berarti, jika seandainya sarana-prasarana dan fasilitas pendidikan pada pesantren di NTB berkualitas sebagaimana halnya di sekolah umum, maka dapat diduga bahwa pilihan "utama dan pertama" orangtua untuk menyekolahkan anaknya adalah "pondok pesantren", bukan sekolah umum.

\section{Sistem Pendidikan Pesantren Hikmatusysyarief NW}

\section{Pengajian Kitab Kuning}

Pada dasarnya, pengajian kitab kuning merupakan proses pembelajaran yang menggunakan litaratur utama bersumber dari kitab kuning. Menurut Nata proses pembelajaran secara sederhana dapat diartikan sebagai kegiatan interaksi dan saling mempengaruhi antara pendidik dan peserta didik, dengan fungsi utama pendidik memberikan materi pelajaran, sedangkan peserta didik menerima pelajaran. ${ }^{19}$ Ini berarti, pengajian kitab kuning adalah suatu interaksi antara tuanguru atau ustadz dengan santri dalam proses belajar mengajar dengan menggunakan kitab kuning sebagai sumber utama pembelajaran.

Peraturan Pemerintah RI Nomor 55/2007 tentang Pendidikan Agama dan Pendidikan Keagamaan Pasal 22 ayat (1) pengajian kitab diselenggarakan dalam rangka mendalami ajaran dan/atau menjadi ahli ilmu agama Islam. Ini menunjukkan, pengajian kitab kuning di pesantren diselenggarakan untuk mengkaji secara mendalam isi dan kandungan al Qur'an dan as-Sunnah dengan pemahaman transformasi kitab kuning sebagai bekal ahli ilmu agama.

Pesantren Hikmatusysyarief, meskipun menyelenggarakan pendidikan formal. Tapi,

${ }^{19}$ Abuddin Nata. 2012. Ilmu Pendidikan Islam. Jakarta: Kencana Prenada Media Group, h. 139.

EDUKASI Volume 12, Nomor 1, Januari-April 2014 107 
tetap menjaga, mempertahankan dan memelihara tradisi pengajian kitab kuning melalui pendidikan kepesantrenan. Menurut Bruinessen, alasan pokok munculnya pesantren adalah untuk mentransmisikan Islam tradisional sebagaimana yang terdapat dalam kitab-kitab klasik yang ditulis berabad-abad yang lalu. Kitab-kitab ini dikenal di Indonesia sebagai kitab kuning. ${ }^{20}$ Sejalan dengan pendapat ini Dhofier mengemukakan, bahwa pengajaran kitab Islam klasik adalah sebagai elemen dasar tradisi pesantren. ${ }^{21}$ Ini berarti, sistem pendidikan pesantren dengan kitab kuning merupakan tradisi yang telah berakar dengan kuat sejak adanya pesantren.

Adapun metode pengajaran kitab kuning di Pesantren Hikamatusysyarief umumnya dilaksanakan dengan "bandongan atau wetonan dan halaqah". Sedangkan metode "sorogan" diterapkan terhadap beberapa santri saja, yaitu santri yang benar-benar memiliki niat yang kuat memperdalam ilmu-ilmu agama melalui pengajian kitab kuning.

Dalam metode "halaqah" santri duduk bersama untuk berdiskusi tentang materi pelajaran, setiap kelompok terdiri dari 5-6 santri dan dipimpin oleh salah seorang santri. Sebelum diskusi dimulai, semua santri dalam pondok tersebut berkumpul (duduk) bersila di teras pondok, sedangkan ustadz pembina duduk di depan memberi penjelasan, pembimbingan dan pengarahan tentang apa saja yang akan didiskusikan dan berapa lama diskusi tersebut. Ketika itu, sesuai jadwal pembelajaran di pondokan, santri mempelajari Kitab Al Kawakibud Durraen dan mendiskusikan Bab "Ismun Maushul". Ustadz Humaidy yang membimbing santri menganjurkan untuk mendiskusikan tentang: bagaimana cara membacanya sesuai Nahwu-Sharf, apa maknanya, apa maksudnya dan bagaimana uraiannya sesuai ilmu Qawaid.

20 Martin van Bruinessen. 2012. Kitab Kuning, Pesantren dan Tarekat. Yogyakarta: Gading Publishing, h. 85.

${ }^{21}$ Zamakhsyari Dhofier. Op. Cit., h. 79.
Diskusi berlangsung selama 45 menit, setelah diskusi selesai setiap kelompok berkumpul kembali, dan ustadz Humaidy kembali duduk di depan untuk memimpin dan mengarahkan jalanya diskusi, masingmasing ketua kelompok membacakan hasil diskusinya. Setelah itu dari anggota kelompok lainnya mengajukan pertanyaan, kemudian ketua dan anggota kelompok men jawabanya dan seterusnya sampai semua ketua kelompok menyampaikan hasil diskusinya. Pada bagian akhir diskusi tersebut, ustadz Humaidy menjelaskan dan menyimpulkan tentang cara membacanya sesuai nahwu sharf, maknanya, maksudnya dan uraiannya sesuai qawaid. ${ }^{22}$ Penerapan metode "bandongan dan halaqah" ini adalah merupakan "cangkokan" dari metode pengajaran madrasah Ash-Shaulatiyah Mekkah yang dikombinasikan dengan Pesantren Pancor Lombok Timur, di mana TGH. Zahid Syarief bertahun-tahun menimbah ilmu di lembaga pendidikan ini.

Begitupun, pengajian kitab kuning di pesantren ini, santri senior (santri MA) diberi kepercayaan dan tanggung jawab untuk membimbing santri yunior (santri MTs), selain bertujuan untuk lebih memantapkan penguasaannya terhadap kitab-kitab yang telah dipelajari, juga santri yunior merasa lebih akrab dengan seniornya, sebab beda usia tidak terlalu jauh, sehingga dalam diskusi seakan-akan tanpa ada jarak, namun mereka tetap ta'dzim kepada seniornya.

Di samping itu, pengajian kitab kuning dilakukan evaluasi yang bertujuan untuk mengetahui sejauhmana tingkat kemampuan (pemahaman dan penguasaan) santri terhadap materi kajian kitab kuning yang telah dipelajari, terutama berkaitan dengan kemampuan: (1) membaca kitab kuning (nahwu-sharf), (2) memahami maknanya, (3) menjelaskan maksudnya, (4) menguraikan dari aspek ilmu

${ }^{22}$ Hasil Observasi Partisipan yang dilakukan di pemondokan binaan ustadz Humaidy pada tanggal 31 Oktober 2012 dan 2 November 2012. 
qowaidnya dan (5) kemampuan mengamalkan kandungan kitab kuning yang telah dikaji. ${ }^{23}$

\section{Kurikulum}

Pendidikan formal (madrasah) di pesantren ini sepenuhnya menggunakan kurikulum Kementerian Agama. Untuk itu, dari aspek kurikulum madrasah, pengasuh pesantren ini sama sekali tidak disibukkan dalam perdebatan tentang berapa persen porsi mata pelajaran umum dan agama di madrasah. Hal ini, pengasuh pesantren memaknainya "kurikulum terintegrasi", yaitu ilmu-ilmu umum melalui mata pelajaran di madrasah dan ilmu-ilmu agama melalui pengajian kitab kuning di pesantren. Meskipun sistem pendidikan pesantren dengan madrasah berbeda, tapi sesungguhnya tidak dapat dipisahkan karena merupakan satu kesatuan yang saling melengkapi, memperkuat dan dibutuhkan masyarakat.

Pengasuh pesantren ini mengembangkan kurikulum Kementerian Agama menjadi MuatanLokal,yaituNahwu-Sharf8jampelajaran perminggu dengan tujuan untuk memperkuat materi pelajaran nahwu-sharf sebagai ilmu alat untuk memperkuat posisi pengajian kitab kuning. Meskipun, sesungguhnya kurikulum di pesantren ini adalah pengasuh "TGH. M Zahid Syarief ", yaitu segala ucapan, sikap, tindakan dan perilaku tuan guru adalah merupakan "hidden kurikulum". Ini menunjukkan bahwa tuan guru dan pesantren merupakan satu keasatuan yang tidak terpisahkan, terutama dalam pembinaan dan pembentukan karakter santri. Artinya, tuan guru menempati posisi dan peran strategis dalam mempertahankan dan memelihara tradisi keilmuan pesantren. Sedangkan, kurikulum kepesantrenan secara tertulis (dokumen) pesantren ini menggunakan kurikulum yang disusun oleh Pesantren Hikmatusysyarief yang isi dan muatannya berbasis "Tafaqquh fi al-din" melalui kajian "Kitab kuning", sebagai berikut:

${ }^{23}$ Wawancara dengan ustadz Humaidy dan ustadz Zulkifli pada tanggal 1 November 2012.
Tabel 1:

Kurikulum Kitab Pesantren

\begin{tabular}{|l|l|}
\hline PELAJARAN & NAMA KITAB \\
\hline Tauhid & $\begin{array}{l}\text { Sullamulddiyanah, Kitabussa'adah, } \\
\text { Husnulhamidiyah, Kifayatul Awam }\end{array}$ \\
\hline Hadits & $\begin{array}{l}\text { Arbain an-Nawawi, Bulughul Maram, } \\
\text { Riyadl ash-Shalihin }\end{array}$ \\
\hline Tafsir & Tafsir Jalalain \\
\hline Akhlaq & $\begin{array}{l}\text { Ta'limul Muta'allim, Akhlaqulil Banin, Akhlagulil } \\
\text { Banat }\end{array}$ \\
\hline $\begin{array}{l}\text { Figh/ } \\
\text { Ushul Figh }\end{array}$ & $\begin{array}{l}\text { Matnul Goyah, Fath al-Qorib, Mabadiu al- } \\
\text { Awwaliyah, waraqat }\end{array}$ \\
\hline Faraid & Mikrajussibyan ila samai ilmu bayan \\
\hline Nahwu-Sharf & $\begin{array}{l}\text { Matan-Syarah Jurumiyyah, Alkawakibuddurriyah, } \\
\text { Syarah Dahlan, Al Awamil, al Kailani, } \\
\text { Matan al Bina', Almaksud, Al Amsilatul Jadidah, } \\
\text { Amsilah at Tashrifiyah, Tsamaratul Janiah, Qawaidul } \\
\text { Lughatul Arabiyyah dan al-Mutammimah }\end{array}$ \\
\hline
\end{tabular}

Kitab-kitab di atas merupakan kitab standar, ini menggambarkan mutu pengajaran kitab kuning di pesantren ini. Olah karena unggulan Pesantren Hikamatusysyarief ini adalah "Nahwu-Sharf". Karena itu, pelajaran nahwu-sharf sebagai ilmu alat lebih menekankan pada gramatika dan sintaksis. Selain itu, kitab-kitab nahwu-sharf sangat umum digunakan dalam pendalaman bahasa Arab dan jenjangnya sangat jelas menunjuk pada pemahaman dan penguasaan yang bertahap, sehingga semakin tinggi semakin kompleks, misalnya; dari mulai al Jurumiyah ke al-Amriti dan seterusnya. Selain itu, kitab-kitab klasik (kitab kuning) tersebut yang diajarkan di pesantren ini, sesuai dengan apa yang telah dikemukakan oleh Dhofier sebagaimana uraian di atas.

Dengan demikian, secara formal di madrasah siswa menerima materi pelajaran sesuai dengan Kurikulum Kementerian Agama yang memuat lebih besar mata pelajaran umum. Tapi, secara nonformal di lingkungan pesantren para santri (siswa madrasah) memperoleh pelajaran keagamaan yang telah disusun berdasarkan tradisi keilmuan dan ideologi keagamaan pesantren ini. 
Tabel 2:

Kurikulum Kitab Pesantren

\begin{tabular}{|c|c|}
\hline \multicolumn{2}{|c|}{$\begin{array}{l}\text { JADWAL \& TEMPAT KEGIATAN SANTRI } \\
\text { Semua Santri Wajib Mukim di Pondok Pesantren } \\
\text { (503 santri)1 }\end{array}$} \\
\hline $\begin{array}{l}\text { Pendidikan Pesantren } \\
\text { (Pengajian Kitab Kuning) }\end{array}$ & $\begin{array}{l}\text { Pendidikan Formal (MTs dan MA) } \\
\text { (Pelajaran Umum) }\end{array}$ \\
\hline $\begin{array}{l}\text { di Ruang Madrasah (MTs \& MA) } \\
\text { di Masjid } \\
\text { di Pomondokan }\end{array}$ & $\begin{array}{l}\text { di Ruang Kelas Madrasah } \\
\text { (MTs \& MA) } \\
\text { di Pomondokan }\end{array}$ \\
\hline $\begin{array}{l}\text { * di Ruang Madrasah (MTs \& MA) } \\
\text { - Santri MA Jam } 14.00-16.00 \\
\text { Santri MTs: } \\
\text { O Jam } 14.00-16.00 \\
\text { O Jam } 19.30-21.30\end{array}$ & $\begin{array}{l}\text { di Ruang Kelas Madrasah } \\
\text { (MTs \& MA) } \\
\text { Santri MTs \& MA } \\
\text { Jam } 07.00-12.30\end{array}$ \\
\hline $\begin{array}{l}\text { di Masjid: } \\
\text { Kajian Tafsir Jalalain } \\
\text { Santri MA ba'da shalat Shubuh } \\
\text { sampai jam } 06.30\end{array}$ & $\begin{array}{l}\text { di Pomondokan: } \\
\text { - Santri MTs \& MA } \\
\text { o Jam 16.00 - Maghrib } \\
\text { ○ Jam 21.30 -23.00 }\end{array}$ \\
\hline $\begin{array}{l}\text { * di Pomondokan: } \\
\text { - Santri MA: } \\
\text { O Ba'da Maghrib - jam } 21.30 \\
\text { o Jam 04.00 -Shubuh } \\
\text { - Santri MTs: } \\
\text { ○ Ba'da Shubuh - jam } 06.30\end{array}$ & $\begin{array}{l}\text { * di Pomondokan: } \\
\text { - Santri MTs: } \\
\circ \quad \text { Ba'da Maghrib - Isya' } \\
\circ \quad \text { Jam 04.00 - Shubuh }\end{array}$ \\
\hline
\end{tabular}

Berdasarkan jadwal pembelajaran di atas, diketahui bahwa alokasi waktu untuk pembelajaran kepesantrenan (pengajian kitab kuning) lebih banyak, jika dibanding dengan pendidikan madrasah. Ini berarti, aktivitas santri di pesantren ini "mengaji kitab kuning sambil belajar di madrasah" bukan "belajar di madrasah sambil mengaji kitab kuning”. Ini menunjukkan, pendidikan pesantren berjalan seirama dengan madrasah (pendidikan formal), sehingga saling mendukung dan memperkuat menuju terwujudnya santri berkualitas baik tafaqquh fi al-din maupun sains dan teknologi. Karena itu, di pesantren ini tidak terkondisikan pertentangan antara ilmu-ilmu agama dengan ilmu umum.

Begitupun, TGH. Zahid Syarief Pengasuh Pesantren Hikmatusysyarief, mengemukan bahwa pesantren ini pada dasarnya bertujuan untuk melahirkan santri yang mampu memahami dan menguasai ajaran-ajaran Islam (tafaqquh fi al-din) melalui dasar-dasar kitab kuning yang diperkuat dengan sains dan teknologi. Karena itu, santri di pesantren ini harus memperkuat "Nahwu-Sharf", sebab ilmu nahwu menjelaskan bagaimana "baris akhir", sedangkan ilmu sharf menjelaskan "baris awal dan tengah". Untuk itu "nahwu-sharf" bagaikan "bapak dan ibu". Jika bapaknya saja atau ibunya saja, mustahil akan berkembang biak. Jadi santri harus menguasai "nahwusharf" inilah kuncinya untuk belajar dan mengusai kitab kuning di pesantren ini. Banyak pesantren mengajarkan santrinya "bahasa arab", bahkan bahasa Inggris, tapi tidak memperkuat "nahwu-sharf" maka santri tersebut lancar berbahasa Arab dan berbahasa Inggris. Namun, santri tersebut tidak mampu mengkaji dan menelaah kitab kuning dengan baik dan benar. ${ }^{24}$

\footnotetext{
${ }^{24}$ Wawancara pada tanggal 2 November 2012.
} 


\section{Ustadz}

Berdasarkan dokumen ${ }^{25}$ yang diperkuat dengan hasil wawancara dengan ustadz Makmun dan ustadz Zulkifli, ${ }^{26}$ diketahui bahwa jumlah ustadz di pesantren ini 34 orang. Menurut jenis kelamin, sebagian besar laki-laki, 25 (73,53\%) orang dan perempuan 9 (26,47\%) orang. Jika dilihat dari tingkat pendidikan, sebagian besar 31 (91,18\%) sarjana (S 1), bahkan terdapat $2(5,88 \%) \mathrm{S} 2$, dan hanya sebagian kecil $3(8,82 \%)$ orang belum sarjana. Tiga orang (ustadz) ini sedang dalam proses penyelesaian tingkat pendidikan sarjana (S 1). Sedangkan jumlah ustadz menurut pengalaman mengajar (masa kerja), juga sebagian besar 31 (91,18\%) ustadz telah memiliki pengalaman mengajar lebih 5 tahun dan hanya sebagian kecil 3 $(8,82 \%)$ ustadz baru memiliki pengalaman mengajar kurang dari 5 tahun.

Profil asatidz di atas, menunjukkan bahwa umumnya telah memenuhi kualifikasi akademik yang didukung pengalaman mengajar memadai. Ini berarti, umumnya asatidz memiliki kompetensi untuk lebih meningkatkan kualitas pendidikan di pesantren ini.

Dari 34 ustadz, di antaranya 13 (38,26\%) orang mengajar di madrasah (pendidikan formal) dan pendidikan kepesantrenan (mengaji kitab kuning) dan 13 ustadz tersebut sebagian besar, 12 (92,31\%) lulusan Pesantren Nahdlatain NW Pancor, di antaranya $4(30,77 \%)$ ustadz lulusan pesantren ini yang melanjutkan ke Pesantren Nahdlatain NW Pancor dan 2 (15,38\%) ustadz lulusan Madrasah AshShaulatiyah Mekkah.

Dengan demikian, umumnya ustadz yang mengajar (mengasuh) pengajian kitab kuning

${ }^{25}$ Dokumen Pondok Pesantren Hikmatusysyarief NW Salut Selat Narmada Lobar, tahun 2012.

${ }^{26}$ Ustadz H. Makmun Ibrahim, SH, M.Si adalah Kepala MA, sedangkan ustadz Zulkifli, S. Pd. I adalah alumni pondok pesantren ini, setelah lulus di MTs melanjutkan ke MA, kemudian melanjutkan studinya ke Fakultas Tarbiyah Jurusan Bahasa Arab UIN Alauddin Makassar. Setelah meraih gelar Sarjana Pendidikan Islam (S.Pd.I) beliau kembali bertugas sebagai pengajar Nahwu-Sharf di pesantren ini sampai sekarang. Wawancara dilakukan, 2 Oktober 2012. di pesantren ini adalah lulusan Pesantren Nahdlatain NW Pancor. Kebijakan pengasuh pesantren yang demikian ini ditetapkan untuk memelihara, kelangsungan dan perubahan (preservation, continuity and change) tujuan Pesantren Hikmatusysyarief yang diilhami oleh sistem pendidikan Pesantren Nahdlatain NW Pancor sebagai pesantren tertua di NTB yang tidak diragukan kualitasnya, terutama penguasaan kitab kuning.

Di samping itu, ustadz yang bertugas pada pendidikan formal(MTs dan MA) yang mengajar mata pelajaran umum, juga perekrutannya dilakukan dengan ketat. Karena itu, guruguru mata pelajaran umum yang diangkat oleh Yayasan Pesantren Hikmatusysyarief NW sebagian besar telah memenuhi kualifikasi akedemik, kompetensi dan sertifikat pendidik.

\section{Pemondokan}

Pada dasarnya penyelenggaraan pendidikan formal (madrasah) di pesantren ini mengikuti sistem pendidikan pesantren, yaitu pengasuh dan para ustadz, khususnya ustadz yang mengajarkan kitab kuning harus mukim di lingkungan pesantren bersama santri. Karena itu, fungsi dan peran pemondokan di pesantren ini tidak hanya sebagai tempat istirahat santri. Tapi, juga sebagai tempat belajar dan pembinaan santri, setiap pemondokan dibina oleh $2-3$ ustadz, sehingga pembinaan santri dapat berjalan secara efektif. Namun, kondisi pemondokan "kurang layak" karena selain daya tampungnya melebihi batas maksimal, juga lampu penerangan kurang terang, vintilasi udara sangat minim dan cenderung kurang bersih.

Pola pembinaan yang dilakukan ustadz di pesantren ini, jika diamati secara cermat setiap aktivitas dan simbol-simbol di pesantren ini, dapat diketahui bahwa pola pembinaan yang dilakukan berdasakan "kekeluargaan dan kekarabatan". Karena itu, para ustadz secara ikhlas mampu berperan sebagai orangtua santri yang kedua. Sebaliknya, para santripun 
secara ikhlas dan penuh "ta'dzim" menganggap ustadz sebagai orangtuanya. ${ }^{27}$

\section{Masjid}

Peran masjid di pesantren ini merupakan salah satu pusat pendidikan, yaitu selain sebagai tempat pengajian kitab kuning. Juga sebagai tempat shalat berjama'ah lima waktu yang wajib diikuti oleh semua santri, tempat latihan khutbah, pidato, diskusi para santri dan kegiatan pendidikan keagamaan lainnya. Menurut Dhofier, masjid merupakan elemen yang tidak dapat dipisahkan dengan pesantren dan dianggap sebagai tempat yang paling tepat untuk mendidik para santri, terutama dalam praktek sembahyang lima waktu, khutbah dan sembahyang Jum'at dan pengajaran kitab Islam klasik..$^{28}$

Oleh karena itu, peran masjid sangat penting dan strategi dalam meningkatkan efektivitas pengajian dan sekaligus dapat meningkatkan kualitas pendidikan, terutama untuk memperkuat tradisi-tradisi pesantren. Namun, masjid di pesantren ini "kurang memadai", hanya berlantai plur semen yang sebagian rusak dan kurang terawat. Sedangkan masjid yang baru masih dalam proses pembangunan yang tak kunjung selesai.

\section{PENUTUP}

\section{Kesimpulan}

1. Pengasuh Pesantren Hikmatusysyarief memiliki latar belakang pendidikan pesantren dengan keahlian bidang kitab kuning (nahwu-sharf) yang "sangat memadai". Hal ini, sangat penting dan strategi untuk tetap mempertahankan dan melesatarikan tradisi kepesantrenan

${ }^{27}$ Hasil Observasi terhadap pembinaan ustadz terhadap santri, baik ketika santri berada di ruang kelas, di masjid maupun di pondokan dan obeservasi terhadap kehidupan santri selama 24 jam. Observasi ini dilakukan pada tanggal 27 September 2012 sampai 3 Oktober 2012 dan tanggal 31 Oktober 2012 sampai 2 November 2012.

${ }^{28}$ Zamakhsyari Dhofier. Op. Cit., h. 49. (tafaqquh fi al-din), khususnya pengajian kitab kuning. Sebab hanyalah pengasuh pesantren yang berlatar belakang pendidikan pesantren dengan keahlian kajian kitab kuning yang sukses memadukan sistem pendidikan pesantren dengan pendidikan madrasah.

1. Sesungguhnya motivasi santri/siswa madrasah terhadap pengajian kitab kuning dapat ditumbuh-kembangkan melalui pembinaan secara efektif oleh asatidz sebagaimana halnya di pesantren ini. Motivasi ini merupakan faktor yang sangat penting dan strategi untuk meraih kesuksesan, baik kesuksesan pengasuh, asatidz maupun santri. Sebab hanyalah santri yang memiliki motivasi kuat mengaji kitab kuning yang sukses mengaji di pesantren yang menyelenggarakan madrasah (pendidikan formal).

2. Sistem pendidikan Pesantren Hikmatusysyarief NW adalah mempertahankan, memperkuat dan menyebarkan nilai-nilai ajaran Islam (tafaqquh $f i$ al-din) melalui unsur-unsur pendidikan pesantren yang terdiri dari: (1) pelaku (tuan guru/ pengasuh, ustadz dan santri), (2) saranaprasarana pendidikan, seperti: rumah tuan guru, pemondokan santri dan ustadz, masjid, ruang belajar madrasah, dan sarana pendidikan lainnya, (3) fasilitas pendidikan, seperti; kurikulum, kitab-kitab, perpustakaan, tata tertib dan sejenisnya. Nilai-nilai dan unsurunsur sistem pendidikan pesantren ini merupakan satu kesatuan yang terpadu (terintegrasi), saling melengkapi dan saling memperkuat pelaksanaan pengajian kitab kuning dan madarash (pendidikan formal) di pesantren ini.

\section{Rekomendasi}

Diharapkan kepada Ditjen Pendidikan Islam Direktorat Pendidikan Diniyah dan Pondok Pesantren Kementerian Agama, selain lebih meningkatkan pembinaannya, juga pembinaan yang dilakukan harus cepat 
dan tepat sasaran. Dalam hal ini, Pesantren Hikmatusysyarief NW Salut Lombok Barat, khususnya berkaitan:

1. Membangun dan/atau merehab pomondokan santri dan masjid, sehingga layak sebagai salah satu pusat pendidikan di lingkungan pesantren.

2. Pembinaan terhadap aspek kebersihan dan kesehatan pemondokan, sehingga pesantren tidak hanya menjaga dan memelihara kesucian pemondokan, tapi juga sangat penting menjaga dan memelihara aspek kebersihannya.

3. Santri berprestasi yang memperoleh beasiswa dari Ditjen Pendidikan Islamuntuk melanjutkan studinya ke perguruan tinggi, khususnya Fakultas Kedokteran setelah lulus segera dikembalikan ke pondok pesantren untuk melakukan pembinaan, terutama dalam hal meningkatkan wawasan, sikap dan perilaku "hidup bersih dan sehat" di lingkungan pesantren.

\section{SUMBER BACAAN}

Azra, Azyumardi (2002): Pendidikan Islam: Tradisi dan Modernisasi Menuju Milenium Baru. Jakarta, Logos Wacana Ilmu,

Basri, Husen Hasan, dkk (2011): Hasil Survei Pengajaran Kitab Kuning di Pondok Pesantren. Jakarta, Puslitbang Pendidikan Agama dan Keagamaan Badan Litbng dan Diklat Kementerian Agama.

Bungin, Burhan (2007): Analisis Data Penelitian Kualitatif. Jakarta, RajaGrafindo Persada.

Burgess, R. G (1984): In the Field: An Introduction to Field Research. London, George Allen \& Unwin.

Bruinessen, Martin van (2012): Kitab Kuning, Pesantren dan Tarekat (Edisi Revisi). Yogyakarta, Gading Publishing.

Dhofier, Zamakhsyari (2011): Tradisi Pesantren: Studi Tentang Pandangan Hidup Kyai dan Visinya Mengenai Masa Depan Indonesia (Edisi Revisi). Jakarta, LP3ES.
Hamidi (2004): Metode Penelitian Kualitatif. Malang, Universitas Muhammadiyah.

Lofland, John \& Lyn H Lofland (1984): Analyzing Social Settings: A. Guide to Qualitative Observation and Analysis. Belmont, Cal., Wads worth Publishing Company.

Mastuhu (1994): Dinamika Sistem Pendidikan Pesantren, Suatu Kajian Tentang Unsur dan Nilai Sistem Pendidikan Pesantren. Jakarta, Indonesian Netherlands Cooperation in Islamic Studies (INIS).

Muhaimin. et. al. (2002): Paradigma Pendidikan Islam. Bandung, Remaja Rosdakarya.

Morissan (2012): Metode Penelitian Survei. Jakarta, Kencana Prenada Media Group.

Nata, Abuddin (2012): Ilmu Pendidikan Islam. Jakarta, Kencana Prenada Media Group.

Moleong, Lexy J (2004): Metodologi Penelitian Kualitatif. Bandung, Remaja Rosdakarya.

Pondok Pesantren Hikmatusysyarief NW (2012): Dokumen Pondok Pesantren Hikmatusysyarief NW, tahun 2012. Salut-Selat Narmada Lombok Barat.

Prasodjo, Sudjoko (1974): Hasil penelitian Sudjoko Prasodjo dan Kafrawi Ridwan (1974) yang menghasilkan antara lain "Diversifikasi Model-Model Pondok Pesantren".

Qomar, Mujamil (2005): Pesantren dari Transformasi Metodologi Menuju Demokratisasi Institusi. Jakarta, Erlangga. 